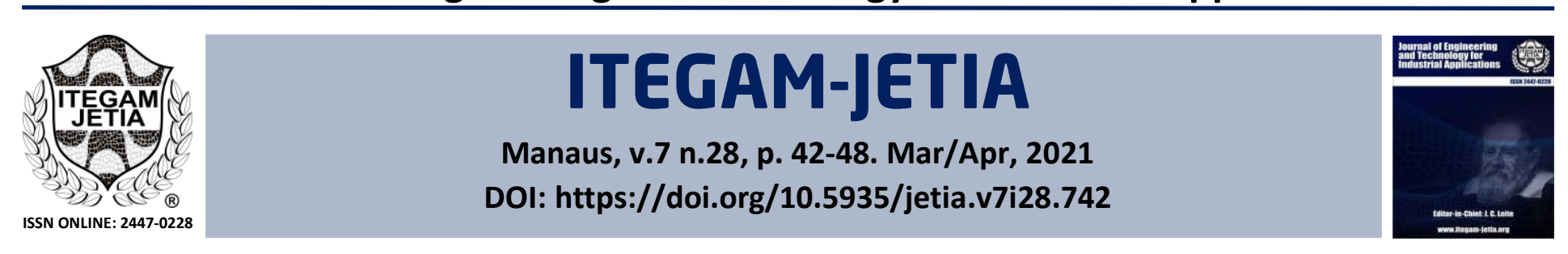

\title{
STRATEGIES TO REDUCE COSTS IN THE PLANNING OF HOUSE BUILDING PROJECTS WITH GOVERNMENT FINANCING FOR LOW- INCOME POPULATIONS
}

\section{Yslene Rocha Kacchba ${ }^{1}$, Everton Luiz de Melo ${ }^{2}$, Elisa Dallarmi Sandrini ${ }^{3}$ and Daiane Maria de Genaro Chiroli*4}

\begin{abstract}
1,2,3 Academic Department of Production Engineering, Federal University of Technology - Paraná, Ponta Grossa, Paraná, Brazil.
${ }^{4}$ Academic Department of Textile Engineering, Federal University of Technology - Paraná, Apucarana, Paraná, Brazil.

${ }^{1}$ http://orcid.org/0000-0002-8320-4783 투, ${ }^{2}$ http://orcid.org/0000-0003-3542-1940 투, ${ }^{3}$ http://orcid.org/0000-0001-6848-9349 (D), ${ }^{4}$ http://orcid.org/0000-0002-9088-406X (i)
\end{abstract}

Email: yslener@utfpr.edu.br, evertonmelo@utfpr.edu.br, elisasandrini93@gmail.com, *daianechiroli@utfpr.edu.br

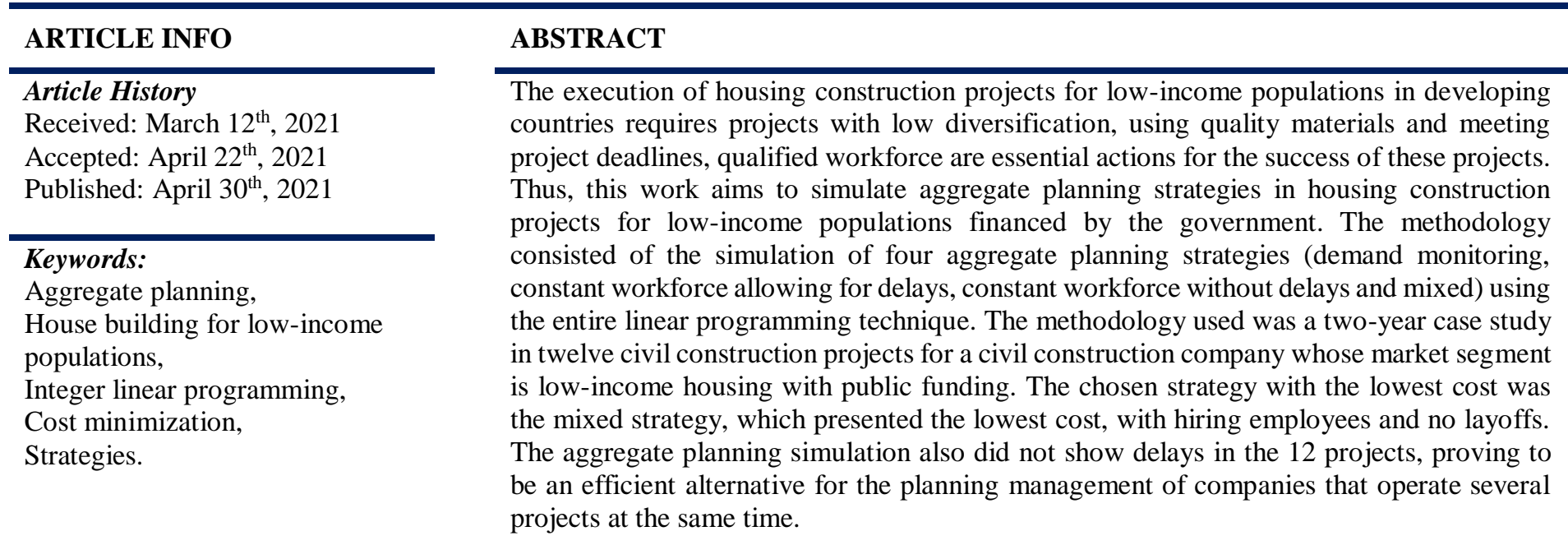

Copyright (02016 by authors and Galileo Institute of Technology and Education of the Amazon (ITEGAM). This work is licensed under the Creative Commons Attribution International License (CC BY 4.0).

\section{INTRODUCTION}

Acting in the civil construction market presents challenges due to projects being increasingly more focused on efficiency related to cost, quality, variety, and time [1-3]. These factors require the skillful planning of the construction project to better execute it. However, for constructions financed by government organs, the cost is the determining factor for obtaining the right to build houses paid by government funds [4][5].

The challenge lies in planning several house-building projects, financed by the government for low-income populations, simultaneously. The projects need to feature similar characteristics: quality materials; execution of construction processes; faster deliveries; and lower costs; according to the government's specifications. Inefficient project planning may cause higher costs and delays in construction process [6-10]. In specific, some works recognized that around $70 \%$ of all construction projects end up in time overruns and cost overruns take regularly up to $14 \%$ of project contract sum [6][11][12]. Thus, poor planning renders the company less competitive than its competitors in a government bidding.

For [6] the management tools most used in civil construction are Critical Path Method (CPM), Earned Value Analysis (EVA), Last Planner System (LPS), Program Evaluation and Review Technique (PERT), Line of Balance (LOB), Flowline and Location Based Management System (LBMS). However, these tools focus on project management and do not act on executing and controlling practical project variables.

For [13], the planning of the variables employed in the execution of construction projects mostly comprises the quantity of materials employed and the numbers of hires and layoffs in the workforce. The construction stages outsourced (electrical wiring, 
structure, painting and textures, among others), square footage built before the deadline, and square footage not built at the deadline (inability to deliver the finished house within the time specified by the project). To plan these variables with several projects happening at the same time in different stages of execution, a practical and detailed tool is needed to identify an optimization of the time and each cost of the projects. An alternative to perform the management of several projects is linear programming in order to minimize time and cost.

In addition to planning and programming the variables of the construction project for a house, it requires the identification of the strategy employed by the construction company throughout the execution of the project. This strategy needs to be different from product planning for consumer goods such as food, for example, since the production systems of civil construction are based on projects and not on assembly or stock.

However, the planning of several projects for the construction of standardized houses can be conducted equally to the planning of conventional products (which already present finished production models and are replicated without great variations). Bringing benefits to the company that operates in this market segment to realize planning these projects in sets and mainly managing to manage the cost variables at the same time in all projects, for example, to minimize the cost of labor in several projects at the same time.

Aggregating project management planning for these buildings with similar characteristics can be a key factor for the success of their execution. However, aggregate planning requires strategies to minimize the costs of these projects, through optimizing the workforce, purchasing materials, finishing house construction earlier during periods of low demand or working with prefabricated products and anticipating the need for subcontracting during periods of high demand to avoid delays. So, focus on these strategies to be carried out in aggregate for various projects.

Thus, the objective of this article is to simulate aggregate planning strategies to reduce costs of several house-building projects financed by the Brazilian government through linear programming executed at the same time. This study is structured in five sections: description of the problem examined of minimizing costs of house projects in an aggregate way; proposal of the model and its mathematical formulation through linear programming, case study illustrating the characteristics of project works performed at different stages of execution, restrictions and resolution of the analyzed case to minimize the costs of aggregate projects, results and conclusions of the simulation of the management of these projects and suggestions for future work.

\section{THEORETICAL REFERENCE}

\section{II.1 AGGREGATE PLANNING IN HOUSE BUILDING PROJECTS}

Thirty-three million Brazilians have nowhere to live presenting an exorbitant housing deficit for the government of this same country [14]. Brazil is a developing country with an unequal income distribution among its own, thus, it increasingly needs public policy projects that help the well-being of its population.

In Brazil, popular housing is financed by the government through projects in which the government buys houses from construction companies and establishes long-term payment plans for low-income people at lower interest rates than other nongovernmental financial entities. a program called "My home my life" (my home my life). The program standardizes the dimensions and style of the houses according to the income range of the possible buyers [15], they are generally small houses with values up to approximately up to Thirty-six thousand dollars.

The ability to build houses at lower costs and in shorter terms is necessary to win the bidding process that chooses the company that will build the set of houses in the program. The company that presents the best project, usually with the lowest cost, wins the government tender. The company can operate in several government financing projects at the same time, as long as its houses have the features of cost, length and quality required by the Brazilian government.

In 2018, when the study was carried out, the My home my life program still provided for the financing of one million homes for the coming years. Thus, in addition to a social context of helping the Brazilian population to have their own homes, good management of various housing construction projects for the My home my life program contributes to the profit of the companies that execute these projects, they increase the amount of employment in the sector and contribute to the growth of material suppliers for the construction of these houses. Developing the local economies where these projects are being carried out

The problem in project management for these buildings lies in the need for planning that meets the low cost production requirements (material, labor, documentation, among others) while building the required square footage on time [16][17] for several projects to be carried out at the same time. Thus, the solution to this problem would be to aggregate projects with similar characteristics as the projects of the Brazilian government program. Aggregate planning comprises a product or product family, project or family of similar projects with small differences that can have their production planning aggregated to minimize costs. This consists of programming the general production capacity or the capacity of several projects in different medium-term phases, which generally varies from three to twenty-four months [18].

Planners in the aggregate planning process to make decisions aimed at general levels of production for each product category to meet fluctuating or uncertain demands in the near future and also consider policies and decisions on hiring, layoff, overtime, back orders, subcontracting and inventory [19].

Companies that carry out home construction projects can employ aggregate planning for projects with the following characteristics: a set of determined production resources, usually the fixed or similar cost as those of government financing; restrictions and square footage, ie similar footage, if they have the same structural features and design. Since the popular housing units follow the same pattern of material, footage and design to reduce costs, aggregate planning can be an efficient and effective alternative in planning these projects.

In aggregate planning, data and demands, mainly, can be classified as deterministic (single objective or diverse objectives) or as uncertain demand found, through fuzzy or stochastic logical models and all with single or multiple objectives. The most used tools to calculate these are Stochastic Programming, Fuzzy, Linear Programming, Goal Programming, Metaheuristics (including Neural Network, Simulated Annealing Algorithm, Tabu Search Algorithm, Genetic Algorithm) and Software Solver [20]. The simulation of discrete hybrid events (DES) and the systems dynamics (SD) methodology are applied to model and simulate the problem of aggregate production planning (APP) [19]. However, [21] use the theory of restrictions to solve the problem of aggregate planning with diffuse demand.

The most used mathematical tool to carry out the simulation and execution of an aggregated planning is the linear programming, since the demand is deterministic, as is the case of the housing 
projects financed by the Brazilian government. Linear programming is one of the optimization techniques used to minimize resources, through mathematical programming using variables and parameters [1][16][22]. [23][24] use linear programming to solve the problem of aggregate planning, while [25-27], also use linear programming, but for uncertain demands. Thus, of course, linear programming can be used to minimize the costs of resources if they behave as a linear function of the quantity of the resource, restricted by meeting demand and respecting production capacity.

Research on aggregate planning, in addition to the characteristics of the demands of the products or projects, addresses in its structure problems about finance, supplies, use of machines, market for multiple products and characteristics of these products, aggregate planning for multiple plants, configuration, workforce characteristics and multiple products [20].

However, according to [22], there are five strategies for aggregate planning that point to the possible ways of using variables and parameters to optimize aggregate planning, as shown in Table 1.

Table 1: Aggregate planning strategies.

\begin{tabular}{|c|c|c|}
\hline Strategies & Positive aspects & Negative aspects \\
\hline $\begin{array}{l}\text { Demand } \\
\text { Monitoring } \\
\text { (AD) }\end{array}$ & $\begin{array}{l}\text { Avoids high carrying costs } \\
\text { and no stock }\end{array}$ & $\begin{array}{l}\text { Affects the workers' } \\
\text { morale, low capability to } \\
\text { monitor the demand in the } \\
\text { short term, risk of } \\
\text { shortages, difficulty in } \\
\text { maintaining quality } \\
\text { standards and service level }\end{array}$ \\
\hline $\begin{array}{c}\text { Constant } \\
\text { workforce } \\
\text { allowing delays } \\
\text { (FTC) }\end{array}$ & $\begin{array}{l}\text { Able to anticipate the } \\
\text { production of units in low- } \\
\text { demand periods. Holds } \\
\text { knowledge in the company } \\
\text { by not firing the workforce } \\
\text { according to demand }\end{array}$ & $\begin{array}{l}\text { Allows delays in the } \\
\text { delivery of the units }\end{array}$ \\
\hline $\begin{array}{c}\text { Constant } \\
\text { workforce not } \\
\text { allowing delays } \\
\text { (FTN) }\end{array}$ & $\begin{array}{l}\text { Does not allow delays in } \\
\text { the delivery of the units }\end{array}$ & $\begin{array}{l}\text { High cost to finish the } \\
\text { units before the deadline } \\
\text { and maintain a constant } \\
\text { workforce }\end{array}$ \\
\hline Mixed (MIS) & Lower costs & $\begin{array}{l}\text { Large variation in hires and } \\
\text { layoffs of the workforce } \\
\text { depending on the period, } \\
\text { units may be delivered late, } \\
\text { among others. }\end{array}$ \\
\hline
\end{tabular}

Source: [28].

Besides the aggregate planning strategies displayed in Table 1 , there are also strategies directed at subcontracting all of the house building processes and utilizing only overtime hours to meet the demand. However, the goal is to minimize costs through aggregate planning strategies without compromising the quality of the product or construction. This situation requires training the workforce, which takes time after the hiring. Layoffs in planning also present problems related to creating a culture of lack of stability and commitment of the collaborators to the company.

\section{MODEL PROPOSAL}

Linear programming is a traditional method to minimize aggregate planning costs with parameters and variables [26]. With the purpose of simulating aggregate planning strategies for house building financed by the government through integer linear programming, the mathematical model employs the following parameters:

$T=$ Number of quadrimesters (four-month periods) to be planned; $t=$ Quadrimester in planning $(t=1, \ldots, T)$;
$D_{t}=$ Demand, in number of square meters built, in the quadrimester $t$

$Y_{t}=$ Ratio of square meters built to acting workforce in the quadrimester;

$C_{r}=$ Unitary cost of layoff per workforce of one square meter of construction;

$C_{c}=$ Unitary cost of hiring per workforce of one square meter of construction;

$C_{f}=$ Workforce cost to build one square meter;

$C_{h}=$ Cost per square meter built with overtime;

$C_{e}=$ Cost, in the quadrimester, of one square meter built to be delivered early;

$C_{s}=$ Cost of subcontracting the construction of one square meter;

$C_{p}=$ Cost of raw materials to build one square meter;

$C_{u}=$ Cost of one square meter built to be delivered late in relation to the planned deadline;

$W_{t}=$ Available workdays in the quadrimester $t$;

The variables of the proposed model are:

$E_{t}=$ Square meters built early at the end of the quadrimester $t$;

$U_{t}=$ Square meters not built at the end of the quadrimester $t$;

$R_{t}=$ Amount of workforce, per square meter of construction, laid off in the quadrimester $t$;

$C_{t}=$ Amount of workforce, per square meter of construction, hired in the quadrimester $t$;

$F_{t}=$ Amount of workforce, per square meter, available in the quadrimester $t$;

$H_{t}=$ Number of square meters built with overtime in the quadrimester $t$;

$L_{t}=$ Limit of square meters that can be built with overtime in the quadrimester $t$

$S_{t}=$ Number of square meters subcontracted in the quadrimester $t$; $P_{t}=$ Number of square meters built in the quadrimester $t$;

Thus, the goal-function is formulated as:

Objective function:

$\sum_{t 1}^{T}\left(C_{f} \cdot F_{t}+C_{h} \cdot H_{t}+C_{c} \cdot C_{t}+C_{d} \cdot D_{t}+C_{e} \cdot E_{t}+C_{u} \cdot U_{t}+C_{p} \cdot P_{t}\right.$
$\left.+C_{s} \cdot S_{t}\right)$

Subject to:

$F_{0}=0$

$F_{t}=F_{t-1}+C_{t}-D_{t}$

$t=1, \ldots, T$

$P_{t} \leq W_{t} \cdot F_{t}+C_{t}-D_{t}$

$t=1, \ldots, T$

$H_{t}=\frac{H_{t} \cdot F_{t}}{5}$

$t=1, \ldots, T$

$E_{0}=0$

$U_{0}=0$

$E_{t-1}+P_{t}+S_{t}=D_{t}+U_{t-1}+E_{t}-U_{t} \quad t=1, \ldots, T$

$F_{t} \geq 0$

$t=1, \ldots, T$

$D_{t} \geq 0$

$t=1, \ldots, T$

$C_{t} \geq 0$

$t=1, \ldots, T$ 


$$
\begin{array}{cl}
H_{t} \geq 0 & t=1, \ldots, T \\
E_{t} \geq 0 & t=1, \ldots, T \\
U_{t} \geq 0 & t=1, \ldots, T \\
S_{t} \geq 0 & t=1, \ldots, T \\
P_{t} \geq 0 & t=1, \ldots, T \\
F_{t} \in \mathbb{Z} & t=1, \ldots, T \\
D_{t} \in \mathbb{Z} & t=1, \ldots, T \\
C_{t} \in \mathbb{Z} & t=1, \ldots, T
\end{array}
$$

The objective-function (1) presents the multiplication of the costs of the variables: workforce, overtime, hires, and layoffs, square meters finished before the deadline, square meters delivered after the deadline, production materials and subcontracting by the multiplication of the number of square meters built in the quadrimester. The first restriction (2) determines that the initial workforce is null. The second restriction is for the variable workforce (3), concerning the relationship between hires and layoffs of the workforce in the constructions in the quadrimester. It is worth stressing that the workforce may be allocated by every construction in planning depending exclusively on its stage and the expertise of the people composing the workforce. The restriction productive capacity (4), in which the workforce is multiplied by the days worked in the quadrimester plus the hires and layoffs, must be lower or equal to the number of square meters built [29]. The restriction overtime (5) presents the total number of overtime hours that may be used by the workforce in the planned period. Finally, the restriction construction balance (6) presents the balance between the demand, houses delivered late, houses delivered early, and subcontracting in the planned period and in the previous period $[16 ; 25]$.

Conducting the four aggregate planning strategies presented by Table 2 (AD, FTC, FTN, MIS) requires transforming some variables into parameters in mathematical modeling. The AD strategy varies the number of hires $\left(C_{t}\right)$, layoffs $\left(R_{t}\right)$, production $\left(P_{t}\right)$, and workforce $\left(F_{t}\right)$ employing the demand $\left(D_{t}\right)$ as a parameter and taking the other variables to zero $\left(S_{t}, E_{t}, H_{t}, L_{t}, U_{t}\right)$ through Equation 20.

$$
F_{t}: \frac{D_{t}}{Y_{t}}
$$

The FTC strategy, which allows delays or failures to deliver the houses setting the layoff variable to zero, has the differential of calculating the workforce through the sum of the demands of all the periods to be planned aggregately by the ratio of square meters built per workforce in the quadrimester. This is illustrated in Equation 21.

$$
F_{t}: \frac{\sum D_{t}}{\sum Y_{t}}
$$

In addition to varying $F_{t}, R_{t}$ and $C_{t}$, the FTC strategy also alters the variable $U_{t}$, which represents the houses that can be delivered late as long as that minimizes the total cost, keeping the variables hires and layoffs null after the second quadrimester. On the other hand, the FTN strategy is constant but does not allow delays in the delivery of houses. Equation 22 illustrates the calculation of the variable $F_{t}$ in the FTN strategy.

$$
F_{t}: \frac{\max \left(D_{t}\right)}{Y_{t}}
$$

The FTN strategy transforms the same variables as the FTC strategy. However, it nullifies the variable $U_{t}$ while tending to increase the values for the variable $E_{t}$. It employs the same restrictions as the FTC, but it works with maximum workforce, that is, the number of workers necessary to meet the highest demand in the quadrimesters. The MIS strategy is programmed with all the parameters, model decision variables, and all the restrictions to minimize planning costs, as displayed by Table 2 .

Table 2: Parameters, variables, and restrictions according to the strategies.

\begin{tabular}{|c|c|c|c|}
\hline Strategy & Parameters & Variables & Restrictions \\
\hline AD & $D_{t}, C_{f}, C_{r}, C_{p}$ and $C_{c}$ & $P_{t}, F_{t}, R_{t}$ and $C_{t}$ & 3 and 20 \\
\hline FTC & $D_{t}, C_{f}, C_{p}, C_{c}, C_{e}$ and $C_{u}$ & $P_{t}, F_{t}, C_{t}, E_{t}$ and $U_{t}$ & 3,8 and 21 \\
\hline FTN & $D_{t}, C_{f}, C_{p}, C_{c}, C_{e}$ and $C_{u}$ & $P_{t}, F_{t}, C_{t}$ and $E_{t}$ & 3,8 and 22 \\
\hline MIS & $D_{t}, C_{f}, C_{r}, C_{p}, C_{c}, C_{e}, C_{u}$, & $P_{t}, F_{t}, R_{t}, C_{t}, E_{t}, U_{t}$, & $3,4,5$ and 8 \\
& $C_{s}, C_{h}$ & $S_{t}$ and $H_{t}$ & \\
\hline
\end{tabular}

Source: adapted from [28].

The summary of the strategies, variables and restrictions was presented in Table 2 in order to identify the best strategy according to the needs of the aggregate planning being programmed. Thus, Figure 1 summarizes the model employed and illustrates the steps required to conduct the aggregate planning according to the strategies identified.

The model was divided into the inputs of the defined parameters, and the variables demand and costs as not defined The second stage involved conducting the integer linear programming for each aggregate planning strategy through the minimization of the planning costs for each simulated strategy. The integer linear programming also pointed to the values of each variable so that they minimize planning costs. Finally, the selected strategy will be between the lowest cost and the positive and negative points presented in Table 1 .

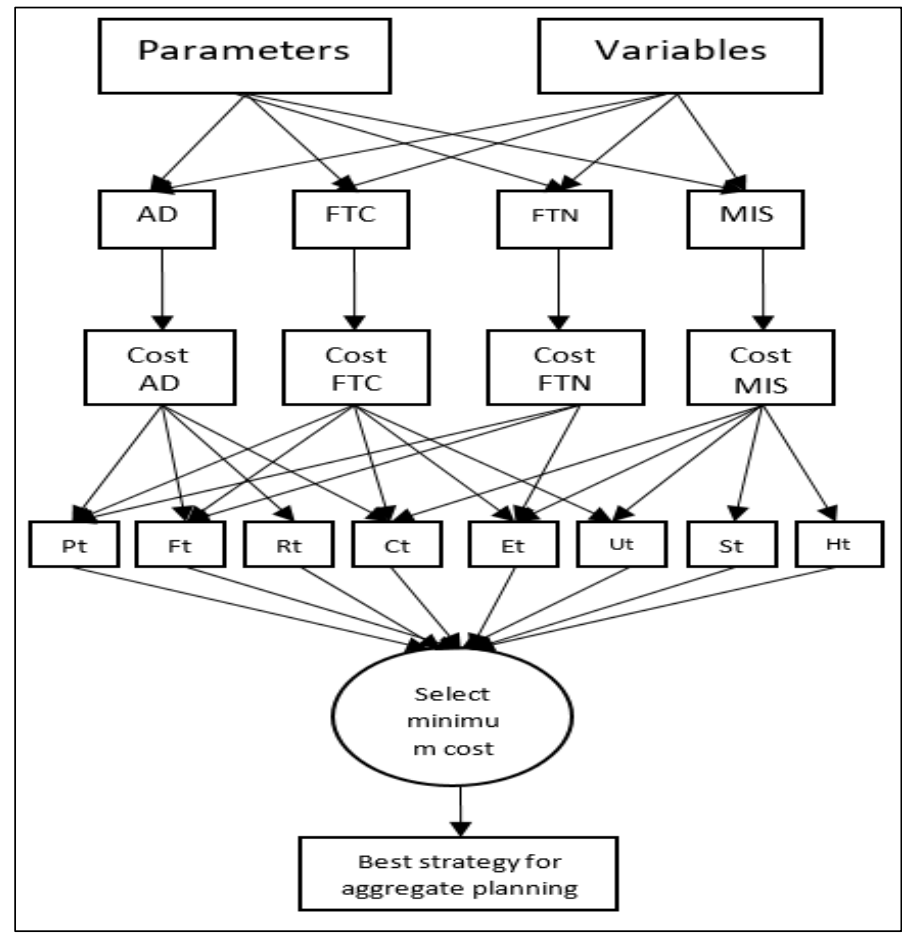

Figure 1: Summary of the proposed model. Source: Authors, (2021). 


\section{PROBLEM DESCRIPTION}

The research company operates in Brazil in the market with the construction of government-funded housing for low-income people. The research was carried out for a 2-year planning with the demand for 12 works carried out in parallel according to the phase of execution of $\%$ of the work to be completed or total footage of all the works to be completed and $172763 \mathrm{~m}^{2}$ built. The construction of the houses to be planned has their lengths, approximately, between $38.5 \mathrm{~m}^{2}$ to $64.64 \mathrm{~m}^{2}$ and reach an age group of buyers who have a minimum monthly income of UU \$ 823. These houses are standardized in living room, kitchen, two bathrooms, three or two bedrooms and a garage. The entire project built in this period has, in addition to the houses: a party room; multisport court; tennis court; playground; bike rack and outdoor gym. The demands for the periods to be planned, as well as the unit quantity of houses are Illustrated in Table 3.

Table 3: Demand of the surveyed construction company.

\begin{tabular}{|c|c|c|}
\hline Project & Demand $\left.\mathbf{( m}^{\mathbf{2}}\right)$ & Amount (unid) \\
\hline $\mathbf{1}$ & 7462 & 138 \\
\hline $\mathbf{2}$ & 12730 & 254 \\
\hline $\mathbf{3}$ & 5934 & 116 \\
\hline $\mathbf{4}$ & 15587 & 272 \\
\hline $\mathbf{5}$ & 13953 & 244 \\
\hline $\mathbf{6}$ & 16243 & 298 \\
\hline $\mathbf{7}$ & 53890 & 1102 \\
\hline $\mathbf{8}$ & 16255 & 286 \\
\hline $\mathbf{9}$ & 20320 & 418 \\
\hline $\mathbf{1 0}$ & 6400 & 104 \\
\hline $\mathbf{1 1}$ & 8371 & 146 \\
\hline $\mathbf{1 2}$ & 15587 & 272 \\
\hline
\end{tabular}

Source: Authors, (2021).

The demand for the square meters to be built was planned according to the delivery date of the projects over a period of two years every four months, with a higher peak demand in the fourth quarter with 53890 square meters built to be delivered only for the construction project of housing 07. However, in month 3 the demand is 5934, thus the differentiation between the maximum and minimum demand 47956 square meters built, even though it is a deterministic demand. This situation presents a difficulty for planning demand with large varieties and forcing the planning to work with options for anticipating the delivery of square meters built in periods of low demand, or with hiring of workforce in these periods, usually temporary workers or subcontractors. of the processes to be carried out for the construction of the houses.

Table 4 distributes the demand for Table 3 into six quarters and indicates the number of square meters that need to be made at each stage of construction of the popular housing to be planned.

Table 4: Demand by period and phases to be planned.

\begin{tabular}{|c|c|c|}
\hline Quaters & Demand $\left(\mathrm{m}^{2}\right)$ & Phases \\
\hline $\mathbf{1}$ & 26683 & $\begin{array}{c}\text { Painting and texture, crockery and metals, } \\
\text { outdoor areas and landscaping }\end{array}$ \\
\hline $\mathbf{2}$ & 23705 & Finishes and coatings \\
\hline $\mathbf{3}$ & 22777 & Hydro sanitary and electrical installations \\
\hline $\mathbf{4}$ & 53890 & Walls, fences, roofs and ceilings \\
\hline $\mathbf{5}$ & 37764 & Foundation and structure of the house \\
\hline $\mathbf{6}$ & 30358 & Project, planning, documentation and budget \\
\hline
\end{tabular}

Source: Authors, (2021).

Even adding the projects and their deliveries every four months, the project for the construction of public housing has the need for a greater workforce in the housing construction project 07 , which was in the construction phase of walls, roof fences and lining at the time of collection data from this research. The meters are only counted as finished when the works finish the Painting and texture phase, crockery and metals, external areas and landscaping according to the footage that needs to be completed in the fourmonth period. As the 12 housing construction projects are in different phases, the planning will only be completed when all the works in in quarterly time organization six have completed the painting and texture phase, crockery and metals, outdoor areas and landscaping and available on the market for sale through government funding.

The costs of the variables per square meter for the construction of the twelve housing projects used in aggregate planning are shown in Table 5.

Table 5: Costs of variables for planning.

\begin{tabular}{|c|c|}
\hline Variável $\left(\mathrm{m}^{2}\right)$ & Cost $(\mathrm{US} \$$ ) \\
\hline Cost per dismissed worker $(\mathrm{Rt})$ & 138.46 \\
\hline Cost per hired worker $(\mathrm{Ct})$ & 81.42 \\
\hline workforce $(\mathrm{Ft})$ & 108.1496 \\
\hline Overtime work $(\mathrm{Ht})$ & 162.2243 \\
\hline Stock $(\mathrm{Et})$ & 0.29 \\
\hline Lack of stock $(\mathrm{Ut})$ & 67.3077 \\
\hline Subcontracting $(\mathrm{St})$ & 408.2973 \\
\hline$(\mathrm{Pt})$ & 245.1542 \\
\hline
\end{tabular}

Source: Authors, (2021).

However, the variables Ft, Et and Ut start the first fourmonth period with a value of 0 , as there are no works in arrears or advances in the construction company and the majority of the workforce is being reformulated and contracted in the location where the work originated. In the case of this 12 projects contracted in the regions of the state of Paraná located in the southern region of Brazil.

\section{RESULTS}

The mathematical modeling to solve the aggregate planning modeled the four strategies according to the preset demand parameters already presented in Table 4 and the variables costs already illustrated in Table 5. The data related to the aggregate planning costs of the 12 projects for the homes for each strategy are shown in Table 6.

Table 6: Aggregate planning cost per strategy.
\begin{tabular}{|c|c|}
\hline Strategy & Cost \\
\hline AD & U\$ $51,223,529.15$ \\
\hline FTC & U\$ $51,236,908.28$ \\
\hline FTN & U\$ $53,567,403.08$ \\
\hline MIS & U\$ $47,758,990.00$ \\
\hline
\end{tabular}

Source: Authors, (2021).

Among the planning strategies aggregating the simulated projects, the FTN presented the highest cost, as it involved the hiring of 113 temporary workers, necessary for production during the four quarters with the highest delivery of houses $\left(53890 \mathrm{~m}^{2}\right)$. It also had a high number of square meters built before the delivery quarter, generating higher planning and inventory costs for project maintenance.

The FTF strategy has the second highest cost, 68 hires, no layoffs and the second highest number of square meters built before the delivery deadline. However, its biggest disadvantage was the delay in the delivery of houses in the 4th and 5th quarters. Thus, this strategy accepts up to 8 months of delay, which can create a negative reputation among customers, even if fines for delays in purchase contracts are duly paid. 
The AD strategy also featured hiring and layoffs in three of the aggregate planned quarters, illustrating the disadvantage of the workforce not having sufficient training to build the necessary homes immediately after hiring. The insecurity of employees regarding instability at work in low-demand quarters (1,2 and 3) is another negative factor in this strategy. However, it still had the second lowest cost in aggregate planning.

Finally, the lowest cost strategy was MIS, with hires in quarters 1 and 3, a workforce of 56 workers during the first three quarters and 23 workers in the 3 quadrimester. In addition to being the optimal solution for presenting the lowest cost, this strategy also did not present layoffs or delays in the delivery of houses. However, the houses were completed in advance during quarters 2 and 3 to meet the high demand in quarters 4 and 5 .

Table 7 presents the results of the decision variables for the six four-month periods and the twelve construction works of popular housing in different stages of construction, according to the four simulated strategies.

Table 7: Number of square meters built per decision variable.

\begin{tabular}{|c|c|c|c|c|c|c|c|}
\hline Strategy & Variable & 1 & 2 & 3 & 4 & 5 & 6 \\
\hline $\mathrm{AD}$ & \multirow{4}{*}{$C_{t}$} & 56 & 0 & 3 & 66 & 0 & 0 \\
\hline FTC & & 68 & 0 & 0 & 0 & 0 & 0 \\
\hline FTN & & 113 & 0 & 0 & 0 & 0 & 0 \\
\hline MIS & & 56 & 0 & 23 & 0 & 0 & 0 \\
\hline $\mathrm{AD}$ & \multirow{4}{*}{$R_{t}$} & 7 & 0 & 0 & 0 & 34 & 15 \\
\hline FTC & & 0 & 0 & 0 & 0 & 0 & 0 \\
\hline FTN & & 0 & 0 & 0 & 0 & 0 & 0 \\
\hline MIS & & 0 & 0 & 0 & 0 & 0 & 0 \\
\hline $\mathrm{AD}$ & \multirow{4}{*}{$F_{t}$} & 56 & 49 & 42 & 112 & 79 & 63 \\
\hline FTC & & 68 & 68 & 68 & 68 & 68 & 68 \\
\hline FTN & & 113 & 113 & 113 & 113 & 113 & 113 \\
\hline MIS & & 56 & 56 & 79 & 79 & 79 & 79 \\
\hline $\mathrm{AD}$ & \multirow{4}{*}{$H_{t}$} & 0 & 0 & 0 & 0 & 0 & 0 \\
\hline FTC & & 0 & 0 & 0 & 0 & 0 & 0 \\
\hline FTN & & 0 & 0 & 0 & 0 & 0 & 0 \\
\hline MIS & & 0 & 0 & 0 & 0 & 0 & 0 \\
\hline $\mathrm{AD}$ & \multirow{4}{*}{$E_{t}$} & 0 & 0 & 0 & 0 & 0 & 0 \\
\hline FTC & & 5957 & 8935 & 10463 & 0 & 0 & 2282 \\
\hline FTN & & 27557 & 30535 & 32063 & 350 & 16476 & 23882 \\
\hline MIS & & 0 & 227 & 15970 & 0 & 0 & 0 \\
\hline $\mathrm{AD}$ & \multirow{4}{*}{$U_{t}$} & 0 & 0 & 0 & 0 & 0 & 0 \\
\hline FTC & & 0 & 0 & 0 & 21250 & 5124 & 0 \\
\hline FTN & & 0 & 0 & 0 & 0 & 0 & 0 \\
\hline MIS & & 0 & 0 & 0 & 0 & 0 & 0 \\
\hline $\mathrm{AD}$ & \multirow{4}{*}{$S_{t}$} & 0 & 0 & 0 & 0 & 0 & 0 \\
\hline FTC & & 0 & 0 & 0 & 0 & 0 & 0 \\
\hline FTN & & 0 & 0 & 0 & 0 & 0 & 0 \\
\hline MIS & & 0 & 0 & 0 & 0 & 0 & 0 \\
\hline $\mathrm{AD}$ & \multirow{4}{*}{$P_{t}$} & 26683 & 23705 & 22177 & 53890 & 37764 & 30358 \\
\hline FTC & & 32640 & 32640 & 32640 & 32640 & 32640 & 32640 \\
\hline FTN & & 54240 & 54240 & 54240 & 54240 & 54240 & 54240 \\
\hline MIS & & 26683 & 23932 & 37920 & 37920 & 37764 & 30258 \\
\hline
\end{tabular}

Source: Authors, (2021).

The decision variables $H_{t}$ and $S_{t}$ showed null results in all simulated aggregate planning strategies, since they would increase their cost greatly. And the $S_{t}$ variable can compromise the quality of the project execution if the supplier of this service does not have the necessary training. The variable $H_{t}$, on the other hand, may be tired in its workforce and decrease its productivity and efficiency. The variable $P_{t}$ points the results according to all the other decision variables employed, mainly the demand for constraint 8 , which leads to the balance of production through the variables stock, demand and scarcity. The AD strategy is the only one in which the variable $P_{t}$ has the same value as the parameter $D_{t}$. However, following the criterion of lower planning costs and not using the layoff variable, the best aggregate planning strategy for construction companies in construction projects financed for lowincome customers was the MIS strategy.

\section{CONCLUSIONS}

Aggregate planning can be a strategy in home construction projects without many variations that seek lower costs and a strategic view of decisions in an aggregate manner such as hiring and firing operators. However, it is essential to guarantee the quality of these constructions and the training of the workforce is essential for this. Thus, strategies for planning aggregate projects that tend to have fewer layoffs to maintain the knowledge of their employees throughout each stage of the project are desirable.

Another significant factor in choosing the best aggregate planning strategy in the case analyzed is the refusal to accept delays in the delivery of houses. Thus, the strategies that accepted layoffs were received as an option in the planning of the Brazilian construction company in this case study, in order to maintain its reputation for punctuality and its competitiveness in the market in which it operates.

The use of whole linear programming to determine the best aggregate planning strategy for the examined company revealed the mixed strategy (MIS) as the main option. It presented the lowest cost (U \$47,758,990.00), a fundamental factor for competition in the public works bidding process, seeking lower costs, and without waivers. The strategy had a $10.84 \%$ lower cost than the FTN strategy, the one with the highest cost. Sometimes, aggregate planning requires employees to act in different stages of each project and in different housing construction projects. Therefore, hiring employees with differentiated knowledge is another strategy to seek the best planning and execution of the construction works 
of popular houses. However, the greatest contribution of this work is in the production systems by project, capable of scheduling the aggregated planning for different projects together. Even though they need to be similar in size and design. This can be an effective differential to carry out the construction works of the house with higher quality, lower cost and within the stipulated period and assist in the decisions of the company's management strategies.

\section{AUTHOR'S CONTRIBUTION}

Conceptualization: Yslene Rocha Kachba, Everton Luiz de Melo, Elisa Dallarmi Sandrini.

Methodology: Yslene Rocha Kachba, Everton Luiz de Melo, Elisa Dallarmi Sandrini and Daiane Maria de Genaro Chiroli.

Investigation: Yslene Rocha Kachba and Elisa Dallarmi Sandrini. Discussion of results: Yslene Rocha Kachba, Everton Luiz de Melo, Elisa Dallarmi Sandrini and Daiane Maria de Genaro Chiroli.

Writing - Original Draft: Yslene Rocha Kachba, Everton Luiz de Melo, Elisa Dallarmi Sandrini.

Writing - Review and Editing: Yslene Rocha Kachba, Everton Luiz de Melo, Elisa Dallarmi Sandrini.

Supervision: Everton Luiz De Melo, Elisa Dallarmi Sandrini. Approval of the final text: Yslene Rocha Kachba, Everton Luiz De Melo, Elisa Dallarmi Sandrini and Daiane Maria De Genaro Chiroli.

\section{REFERENCES}

[1] Prata, A. P., Pitombeira - Neto, A. R., Sales, C. J. M.G. An integer linear model for the multiperiod production planning of precast concrete beams. Journal of Construction Engineering and Management, 141 (4) 2015. https://doi.org/10.1061/(ASCE)CO.1943-7862.0001280.

[2] Firouzi, A., Yang, W., Li, C. Q. Prediction of Total Cost of Construction Project with Dependent Cost Items. Journal of Construction Engineering and Management, 142 (12), 2016. https://doi.org/10.1061/(ASCE)CO.1943-7862.0001280.

[3] Borges, W. F., Mário, P. C. Five project-duration control methods in time units: case study of a linearly distributed planned value. Journal of Construction $\begin{array}{llll}\text { Engineering and } & \text { Management, } & \end{array}$ https://doi.org/10.1061/(ASCE)CO.1943-7862.0001280.

[4] Sinesilassiea, E. G., Tabishb, S. Z. S., Jhaa, K. N. Critical factors affecting cost performance: a case of Ethiopian public construction projects. International Journal of Construction Management, $17 \quad$ (1), 24-49, 2017. https://doi.org/10.1061/(ASCE)CO.1943-7862.0001280.

[5] Love, P. E. D, Irani, Z., Smith,J., Regan, M., Liu, J. Cost performance of public infrastructure projects: the nemesis and nirvana of change-orders. Production $\begin{array}{lllll}\text { Planning \& } \quad \text { Control, } 28 \quad(13), & 1081-1092, & \end{array}$ https://doi.org/10.1080/09537287.2011.631595.

[6] Dallasega, P., Marengo, E., Revolti, A. Strengths and shortcomings of methodologies for production planning and control of construction projects: a systematic literature review and future perspectives. Journal Production Planning \& Control, 2020. https://doi.org/10.1080/09537287.2020.1725170.

[7] Shouten, C., and R. Wilson. Almost Two Thirds of Projects were Late in Past 12 Months. Architect's Journal. $15 \quad$ (1). 2015. https://www.architectsjournal.co.uk/home/almost-two-thirds-of-projects-werelatein-past-12-months/8689116.article.

[8] Emuze, F. Qualitative Content Analysis from the Lean Construction Perspective: A Focus on Supply Chain Management. Acta Structilia, 19 (1), 1-18. 2021

[9] Olanrewaju, A. L., and A. R. Abulaziz. An Overview of the Construction Industry. In Building Maintenance Processes and Practices: The Case of a Fast Developing Country, edited by A. A.-A. Olanrewaju, 9-34. 2015. Singapore: Springer.

[10] Hussin, J. M., I. A. Rahman, and A. H. Memon. The Way Forward in Sustainable Construction: Issues and Challenges. International Journal of Advances in Applied Sciences 2 (1), 15-24. 2013. doi:10.11591/ijaas.v2i1.1321.
[11] Dixon, W. The Impacts of Construction and the Built Environment.Briefing Notes, Willmott-Dixon Group. 2010.

[12] Ola-Adisa, E., Y. C. Sati, and I. I. Ojonigwa. An Architectural Approach to Solid Waste Management on Selected Building Construction Sites in Bauchi. International Journal of Emerging Engineering Research and Technology, 3 (12), $67-77,2015$

[13] Tian, X., Mohamed, Y., and AbouRizk, S. Simulation-based aggregate planning of batchplant operations. Canadian Journal of Civil Engineering, 37 (10), 1277-1288, 2010. https://doi.org/10.1139/L10-071.

[14] United Nations. World Social Report 2020: Inequality: a major threat to socia progress. 2018. UN. https://trello.com/c/JMvJtE8B/9-media-advisory.

[15] Klink, J.,Denaldi, R. On financialization and state spatial fixes in Brazil. A geographical and historical interpretation of the housing program My House My Life. Habitat International, 44, 220-226, 2014.https://doi.org/10.1016/j.habitatint.2014.06.001.

[16] Mezghania, M., Loukila, T., Aoun, B. Aggregate planning through the imprecise goal programming model: integration of the manager's preferences International transactions in operational research, 19, 581-597, 2021 https://doi.org/10.1111/j.1475-3995.2012.00844.x.

[17] Chakrabortty, R. K., Hasin, A. A. M, Sarker, R. A., Essam, D. L. A possibilistic environment based particle swarm optimization for aggregate production planning. Computers \& Industrial Engineering, 88(1), 366-377, 2015 https://doi.org/10.1016/i.cie.2015.07.021.

[18] Makui, A. Heydari, M. Aazami, A., Dehghani, E. Accelerating Bender decomposition approach for robust aggregate production planning of products with a very limited expiration date. Computers \& Industrial Engineering. 100 (1), 34-51, 2016. https://doi.org/10.1016/j.cie.2016.08.005

[19] Jamalnia, A., Feili, A. A simulation testing and analysis of aggregate production planning strategies. Production Planning \& Control, 24 (6), 423-448, 2013. https://doi.org/10.1080/09537287.2011.631595.

[20] Cheraghalikhani, A., Khoshalhan, F. and Mokhtari, H. Aggregate production planning: A literature review and future research directions. International Journal of $\begin{array}{llll}\text { Industrial Engineering Computations. } & 10 & \text { (2) } 309-330,2018 .\end{array}$ https://doi.org/10.5267/j.ijiec.2018.6.002.

[21] Phruksaphanrat, B. Ario, O. and Pisal, Y. Aggregate production planning with fuzzy demand and variable system capacity based on theory of constraints measures International Journal of Industrial Engineering, 18(5), 219-231, 2011.

[22] Munhoz, J. R., Morabito, R. Optimization approaches to support decision making in the production planning of a citrus company: A Brazilian case study. Computers and Electronics in Agriculture, 107(6), 45-57, 2014 https://doi.org/10.1016/j.compag.2014.05.016.

[23] Liang, T. F. Application of interactive possibilistic linear programming to aggregate production planning with multiple imprecise objectives. Production Planning and Control, 18(7), 548-560, 2007.

[24] Erfanian, M., Pirayesh, M. Integration aggregate production planning and maintenance using mixed integer linear programming. In Industrial Engineering and Engineering Management (IEEM), 2016 IEEE International Conference on (pp 927-930). IEEE.

[25] Wang, S. C., Yeh, M. F. A modified particle swarm optimization for aggregate production planning. Expert Systems with Applications, 41, 3069-3077, 2014 https://doi.org/10.1016/j.eswa.2013.10.038.

[26] Entezaminia, A., Heydari, M., Rahmani, D. A multi-objective model for multiproduct multi-site aggregate production planning in a green supply chain: Considering collection and recycling centers. Journal of Manufacturing Systems, 40 (7), 63-75, 2016. https://doi.org/10.1016/j.jmsy.2016.06.004.

[27] Demirel, E. Ozekan, E. e Lim, C. Aggregate planning with flexibility requirements profile. International Journal of Production Economics, 19 (8), 45-58, 2018. https://doi.org/10.1016/j.ijpe.2018.05.001.

[28] Fernandes, F.C.F., Goldinho Filho, M.. Planejamento e controle da Produção dos fundamentos ao essencial. 2010. São Paulo: Atlas.

[29] Techawiboonwong, T., Yenradee, P. Aggregate production planning with workforce transferring plan for multiple product types. Production Planning \& Control, 14 (5), 447-458, 2003. https://doi.org/10.1080/09537287.2011.631595. 